\title{
Protocol for Membracidae inventory (Hemiptera, Auchenorrhyncha, Membracoidea): what are the ideal collection methods for the Atlantic Forest?
}

\author{
Valberta Alves Cabral', Antonio José Creão-Duarte ${ }^{I}$, Aline Lourenço ${ }^{I}$, Carolina Nunes Liberal ${ }^{I}$, Alessandre \\ Pereira-Colavite ${ }^{1 *(1)}$ \\ ${ }^{1}$ Universidade Federal da Paraíba, Departamento de Sistemática e Ecologia, Campus I, Castelo Branco s/n, \\ CEP 58.051-900, João Pessoa, PB, Brasil. \\ * Corresponding author: Alessandre Pereira-Colavite, e-mail: alepercol@gmail.com
}

CABRAL,A.C., CREÃO-DUARTE, A. J., LOURENÇO, A., LIBERAL, C. N., PEREIRA-COLAVITE, A. Protocol for Membracidae inventory (Hemiptera, Auchenorrhyncha, Membracoidea): what are the ideal collection methods for the Atlantic Forest?. Biota Neotropica 20(2): e20190878. https://doi.org/10.1590/1676-0611-BN-2019-0878.

\begin{abstract}
Membracidae are phytophagous insects that present different types of behavior, requiring a specific protocol for fast and efficient collection. This article evaluates the best methods for sampling these insects in Atlantic Forest areas. The protocol was applied in four areas of the Atlantic Forest in Paraíba state, Brazil, and involved a team of four people at a cost of US $\$ 180$ per area. Each area contained 100 sampling units subdivided into 30 yellow sticky cards in the canopy and 30 yellow sticky cards in the lower stratum, 30 active collections and 10 light traps. In total, 2,678 specimens belonging to 91 species were sampled. The highest abundance and richness values were obtained using active collection $(\mathrm{N}=1,517 ; \mathrm{S}=42)$ and cards in the canopy $(\mathrm{N}=345 ; \mathrm{S}=53)$. All methods exhibited high complementarity, with more than half of the species $(\mathrm{S}=50 ; 54.35 \%)$ recorded exclusively by only one of the methods applied. Similarity analysis revealed that active collection differs significantly from all other methods $(\mathrm{R}=0.10, \mathrm{p}=0.0001)$ and that the sticky cards in the canopy differ from the collection in the lower stratum $(\mathrm{p}=0.0001)$, whereas the other method pairs did not exhibit significant differences. In all areas, the active collection, the sticky cards in the canopy and the lower stratum had the best sample sufficiency, with at least $60 \%$ of the estimated values. To inventory Membracidae specimens in areas of the Atlantic Forest, a protocol that combines different collection methods is required, which in principle requires more time and expense. However, it is worth noting that it is possible to adjust this protocol according to the researcher's need. For a faster survey that includes the largest number of species, we suggest a combination of active collection and a light trap.

Keywords: Biodiversity; Brazil; Estimators; List of species; Sampling standardization; Treehoppers.
\end{abstract}

\section{Protocolo para inventário de Membracidae (Hemiptera, Auchenorrhyncha, Membracoidea): quais os métodos de coleta ideais para Floresta Atlântica?}

Resumo: Membracídeos são insetos fitófagos que apresentam diferentes tipos de comportamento, o que requer um protocolo específico para uma coleta rápida e eficiente. Este artigo avalia quais os melhores métodos para amostragem desses insetos em áreas de Floresta Atlântica. O protocolo foi aplicado em quatro áreas de Floresta Atlântica na Paraíba e envolveu uma equipe de quatro pessoas, ao custo de U\$180 por área. Contém 100 unidades amostrais subdividas em 30 cartões adesivos amarelos no dossel, e 30 no estrato inferior, 30 coletas ativas e 10 armadilhas luminosas. No total foram amostrados 2.678 espécimes pertencentes a 91 espécies. As maiores abundâncias e valores de riqueza foram obtidos usando a coleta ativa $(\mathrm{N}=1.517 ; \mathrm{S}=42)$ e os cartões do dossel $(\mathrm{N}=345 ; \mathrm{S}=53)$. Todos os métodos apresentaram alta complementaridade, com mais da metade das espécies $(S=50 ; 54,35 \%)$ registradas exclusivamente por apenas um dos métodos aplicados. A análise de similaridade mostrou que a coleta ativa difere significativamente de todos os outros métodos $(\mathrm{R}=0,10 ; \mathrm{p}=0,0001)$, e que os cartões adesivos no dossel diferem da coleta no estrato inferior $(\mathrm{p}=0,0001)$, enquanto os outros pares de métodos não apresentaram diferenças significativas. Em todas as áreas, a coleta ativa, os cartões adesivos no dossel e no estrato inferior, respectivamente, foram os que apresentaram melhor suficiência amostral, com valores de no mínimo $60 \%$ do estimado. Foi demonstrado que, para inventariar membracídeos em áreas de Floresta Atlântica, é necessário um protocolo que combine diferentes métodos de coleta, o que à priori, demanda mais tempo e custo. Contudo, vale ressaltar que é possível ajustar este protocolo de acordo com a necessidade do pesquisador. Indicamos que para um levantamento mais rápido e que contemple o maior número de espécies, o ideal é utilizar uma combinação de coleta ativa e armadilha luminosa.

Palavras-chave: Biodiversidade; Brasil; Estimadores; Lista de espécies; Amostragem padronizada; Soldadinhos. 


\section{Introduction}

Extensive quantitative samplings are typically problematic because they require long periods of time, a large number of people and, consequently, significant resources (Cardoso 2009, Magurran 2011). Because increasingly fewer resources have been allocated for these purposes, rapid survey methods or protocols have become more popular (Oliver \& Beattie 1996, Duelli 1997, Jones \& Eggleton 2000, Muelelwa et al. 2010). In this context, rapid biodiversity assessments (RBA) have been increasingly implemented in inventory and monitoring studies, being used for diverse taxa in different habitats and ecosystems (ants/litter: Alonso \& Agosti 2000, Agosti \& Alonso 2000; spiders/ Mediterranean oak forests: Cardoso et al. 2008; ants: Souza et al. 2012; scarab beetles/Amazon: Braga et al. 2013).

The use of RBA should ensure that the diversity of the taxon sampled reflects its composition in the areas where it is applied (Jones \& Eggleton 2000, Gillies et al. 2009). For this purpose, collection protocols are developed or adapted (Borisko et al. 2007, Buss \& Borges 2008, Cardoso et al. 2008) using numerous collection methods to sample the largest possible number of representatives of the species that are part of a given assembly.

Well-structured protocols, in addition to facilitating inventory and monitoring studies, ensure the possibility of data sharing in comparative studies based on the use of these protocols (Gotelli \& Colwell 2001). In the present study, we present a sampling protocol to inventory Membracidae in the Atlantic Forest. The family currently has about 3,500 described species and 428 genera, classified into nine subfamilies (Deitz \& Wallace 2010). In Brazil, there are about 690 described species and 121 genera (Evangelista et al. 2019). Although membracids have a worldwide distribution, eight subfamilies are restricted to the New World.

Membracids exhibit a complex and unique variety of pronotal forms, with projections of various shapes and colors, including mimicry, camouflage, aposematism, and defense against predators (Evangelista et al. 2017). Treehoppers exhibit interaction with more than 100 herbaceous and woody host plant families, and they are considered pests in some due to damage caused by egg insertion into plant tissue (Deitz \& Wallace 2010); these insects establish an intricate mutualistic network with ant species, receiving protection from predators and parasitoids while providing honeydew - a sugary product resulting from the metabolism of their carbohydrate-rich diet - to the formicids (Funkhouser 1950, Wood 1993). In many cases, these relationships overlap with a wide spectrum of social regimes, ranging from solitary individuals to gregarious species with offspring defense and maternal care behaviors (Lin et al. 2004, Lin 2006).

In addition, we highlight the fact that membracids were listed as good biological indicators of environmental changes, with broad possibilities of being employed in monitoring studies (Brown 1997). Recently, studies conducted in phytogeographical zones of rainforest (southern Brazil) on ecological networks involving these insects, their attendant ants (mutualistic interactions) and host plants (antagonistic interaction), were developed to better understand the role of these insects in the ecosystems (Gadelha et al. 2016, Gadelha et al. 2017).

The application of this protocol presupposes the following question: what is the best method for collecting Membracidae in the Atlantic Forest? In this context, considering that these insects inhabit different niches, such as the canopy, border and lower stratum of the forest, we aimed to evaluate the efficiency of different collection methods that allow capture of these insects in these locations, and to test the hypothesis that a combination of different methods is necessary to inventory the diversity of Membracidae in areas of the Atlantic Forest.

\section{Material and Methods}

\section{Study areas}

The protocol was applied from May 2015 to April 2016 in four areas of the Atlantic Forest of Paraíba, which are subject to a mean annual temperature of $25^{\circ} \mathrm{C}, 80 \%$ relative humidity, approximately $1,700 \mathrm{~mm}$ of rainfall and a warm humid tropical climate, type As' in the Köppen classification (Alvares et al. 2013): Area 1 - Refúgio da Vida Silvestre (Wildlife Refuge; RVS) Mata do Buraquinho (519.75 ha), located in the urban perimeter of the municipality of João Pessoa (0708'38'S; 3451'34'W); Area 2 - Reserva Particular do Patrimônio Natural (Private Natural Heritage Reserve; RPPN) Engenho Gargaú (1,058.6 ha), located in the municipality of Santa Rita, $\left(07^{\circ} 01^{\prime} 52^{\prime \prime}\right.$; $34^{\circ} 57^{\prime} 41^{\prime \prime}$ ), approximately $15 \mathrm{~km}$ from João Pessoa; Area 3 - Reserva Biológica (Biological Reserve; REBIO) Guaribas (SEMA 2 - 3,016.09 ha), located in the municipalities of Mamanguape ( $06^{\circ} 40^{\prime} 40^{\prime \prime} \mathrm{S}$; $\left.41^{\circ} 12^{\prime} 47^{\prime \prime} \mathrm{W}\right)$ and Rio Tinto (06 $\left.44^{\circ} 59^{\prime}{ }^{\prime} \mathrm{S} ; 4^{\circ} 07^{\prime} 11^{\prime \prime} \mathrm{W}\right), 51 \mathrm{~km}$ from João Pessoa; and Area 4 - RPPN Fazenda Pacatuba (Pacatuba Farm; 266.53 ha) (702'33''S; $\left.35^{\circ} 08^{\prime} 14^{\prime \prime} \mathrm{W}\right)$, located in the district of Santa Helena, municipality of Sapé, 47 km from João Pessoa.

\section{Collection methods}

Samples were collected by four people for seven days, the first and last days being used to place and remove sticky cards, respectively. The sampling method was based on sampling units (Magurran 2011, p. 143) because the presence of gregarious species in Membracidae could cause distortions if the sampling was based on the number of individuals.

The samplings used 100 sampling units per area using the following capture methods: 60 double-sided yellow sticky cards (Promip (C) (23 $\mathrm{x} 11 \mathrm{~cm} / \mathrm{side}$ ), distributed in the canopy (30) and in the lower stratum (30); 10 nocturnal collections, on a white cloth background $(2 \times 2$ $\mathrm{m})$, with mixed mercury light $(250 \mathrm{~W}$ and $220 \mathrm{v})$, fed by a por Table generator, featuring a two-cycle motor with a frequency of $60 \mathrm{~Hz}$ and $\sim 700 \mathrm{~W}$; and 30 active collections (manual process) using capture nets or directly the killing jars.

Each sticky card corresponds to one sampling unit. The sticky cards in the canopy were distributed $50 \mathrm{~m}$ from the border, near the trails inside the forest, at least $30 \mathrm{~m}$ apart from each other, using a slingshot with metal support, high-speed throwing lines and yellow Durepox (C) spheres. The sticky cards of the lower stratum were arranged $1.5 \mathrm{~m}$ above ground level, beginning $50 \mathrm{~m}$ from the border, approximately 20 $\mathrm{m}$ apart. The sampling time for these collection methods was five days.

The light trap operated from 6:00 pm to 9:00 pm, with collection points spaced $100 \mathrm{~m}$ apart, and each sampling unit corresponded to 90 minutes of collection. In the active collection, each sampling unit corresponded to the inspection of the plants at the border, up to $2 \mathrm{~m}$ in height, along $30 \mathrm{~m}$, interspersed by $20 \mathrm{~m}$, for a total transect of $900 \mathrm{~m}$. Once well represented in the active collection (more than 50 specimens), species were no longer captured, and only the abundance was recorded. 


\section{Material preparation}

Insects collected with sticky cards were subjected to a glue removal procedure by immersion in $\operatorname{Varsol}^{\circledR}(24 \mathrm{~h})$ and acetone $\left(\mathrm{C}_{3} \mathrm{H}_{6} \mathrm{O}\right)(24 \mathrm{~h})$. It is important to note that the collection on sticky cards rarely causes damage that prevents the taxonomic identification or inclusion of specimens in the entomological collections, even because membracids have a hard and well sclerotized cuticle. However, our field experience suggests that as soon as the sticky cards are removed from the plants, specimens should be carefully transferred with forceps to a flask with the glue remover, and the sticky cards with insects still adhered to the glue should never be closed.

After being assembled and dried, the specimens were incorporated into the collection of the Entomological Collection of the Departamento de Sistemática e Ecologia (Department of Systematics and Ecology; DSEC) at the Federal University of Paraíba (UFPB).

\section{Data analysis}

Data on abundance, species richness and composition were analyzed according to area and collection method. Species with at least ten collected individuals were considered restricted to one area or method. The number of species shared and unique to each method was illustrated in a Venn diagram built using the Venny 2.1 program (Oliveros 2015).

The efficiency of each method was measured based on the mean accumulation of species per sampling unit. The relationship between species richness and abundance, per method, was calculated using a simple linear regression. The methods were compared by rarefaction, considering the accumulation of species according to abundance.

To test the similarity between the methods according to species composition, an analysis of similarity (ANOSIM) was carried out using the Bray-Curtis index (9,999 permutations) and Bonferroni sequential correction. The Jaccard similarity index was also calculated to analyze the complementarity between the collection methods used.

Regression, rarefaction, ANOSIM and Jaccard index analyses were performed using the program Past 3.21 (Hammer et al. 2001).

Nonparametric estimators of species richness were applied to each area when the four collection methods were used simultaneously and separately. To verify the sample sufficiency, the observed richness was compared to the mean estimate obtained from the abundance (ACE and Chao1) and species incidence estimators (ICE, Chao2 Jackknife 1 and 2, and Bootstrap). Estimates were obtained using the software EstimateS 9.1.0 (Colwell 2013).

\section{Results}

A total of 2,678 specimens belonging to 91 species of 44 genera (Table 1) were collected. The most abundant species was Bolbonota melaena (Germar, 1835) $(\mathrm{N}=366)$, which, together with Harmonides dispar (Fabricius, 1803) ( $\mathrm{N}=317)$, Enchenopa squamigera (Linnaeus, 1758) $(\mathrm{N}=258)$ and Leioscyta spiralis (Haviland, 1925) $(\mathrm{N}=208)$, corresponded to $42.9 \%$ of all specimens collected. Among the four most abundant species, $H$. dispar was the species were collected $(\mathrm{N}=26$, $8,2 \%$ ) by active collection, but. It was the most collected species using the light trap method $(\mathrm{N}=87 ; 27.4 \%)$, although most of its specimens $(64.4 \%)$ were recorded in sticky cards in both the canopy $(\mathrm{N}=89$; $28.1 \%)$ and in the lower stratum $(\mathrm{N}=115 ; 36.3 \%)$.
The method that collected the greatest abundance was active collection ( $\mathrm{N}=1,517$ or $56.65 \%)$, followed by the card in the canopy $(\mathrm{N}=542$ or $20.24 \%)$, light attraction $(\mathrm{N}=345$ or $12.88 \%)$, and card in the lower stratum $(\mathrm{N}=274$ or $10.23 \%)$ methods. The method that recorded the highest number of species was the one that used sticky cards in the canopy ( $\mathrm{S}=53)$, followed by the methods of active collection $(\mathrm{S}=42)$, light trap $(\mathrm{S}=42)$ and sticky cards in the lower stratum $(\mathrm{S}=22)$. The accumulation of species revealed that the addition of new species is greater per sampling unit using the light trap (1.05 species added to each sampling unit). The use of sticky cards in the lower stratum was the least productive method and required an average of 5.5 cards for new records of species ( 0.18 species added per card) (Table 2$)$.

Species richness exhibited a positive and significant relationship with abundance in all methods applied, with greater use of light traps. When comparing the methods by rarefaction (cutoff point of 261 individuals), the most efficient methods were those that used sticky cards in the canopy $(\mathrm{S}=42.71 \pm 2.31)$ and collection with light traps $(\mathrm{S}=37.14 \pm 1.69)$, with no significant difference between both. Active collection ( $\mathrm{S}=27.40 \pm 2.12)$ and sticky cards in the lower stratum ( $\mathrm{S}$ $=21.61 \pm 0.60)$ are the methods with the lowest species richness in rarefaction (Figure 1).

All methods exhibited high complementarity (at least 70\%) (Table 3). More than half of the species ( $\mathrm{S}=50 ; 54.35 \%)$ were recorded exclusively by one of the methods applied (Active - 14 spp.; Canopy - 17 spp.; Lower - 2 spp.; Light - 16 spp.). However, most species were not considered restricted to the method because they had a small number of specimens (eight or fewer individuals). Species that were considered restricted were recorded only in the active collection $(S=9)$ and with sticky cards in the canopy $(\mathrm{S}=2)$. Of the 91 species recorded, only $20(21.98 \%)$ were shared by at least three of the four collection methods used, and of these, five species had individuals collected in all methods (Enchenopa gladius (Fabricius, 1803), Enchenopa monoceros (Germar, 1821), Erechtia sp. 1, Harmonides dispar and Horiola picta (Coquebert, 1801)) (Figure 2 and Table 1).

The ANOSIM revealed that there are significant differences in species composition according to the collection $\operatorname{method}(\mathrm{R}=0.10 ; \mathrm{p}=0.0001)$, and active collection differs from all other methods. The collection with sticky cards in the canopy differs from collection in the lower stratum $(p=0.0001)$ but has a composition similar to that of collection with a light trap $(p=0.98)$. Additionally, no significant differences in species composition were found between the collection methods with sticky cards in the lower stratum and the use of light traps $(\mathrm{p}=0.15)$.

All areas were sufficiently well sampled when the four methods were used concomitantly (Table 4). By analyzing the methods separately in each area, the active collection and the sticky cards in the canopy and lower stratum were those that exhibited the best sampling sufficiency, with values that were at least $60 \%$ of estimated. The light trap, however, exhibited values below $50 \%$ of sample sufficiency for most areas (Table 5).

Application of the protocol required the presence of four people/ area for seven days, and two days were used to place and remove cards. The 100 sampling units compose the number of samples that optimizes time, sample effort and cost, estimated at US $\$ 180$ dollars/seven days of collection. This value meets the food requirements, purchase of sticky cards, throwing lines and fuel for the light trap; however, reducing the 
Table 1. Membracidae collected in four areas of the Atlantic Forest of Paraíba: EGG, RPPN Engenho Gargaú; FZP, RPPN Fazenda Pacatuba; MTB, RVS Mata do Buraquinho; RBG, Reserva Biológica Guaribas, using the methods of active collection (A), sticky cards in the canopy (B), sticky cards in the lower stratum (C) and a light trap (D). * restricted to active collection; ** restricted to canopy collection.

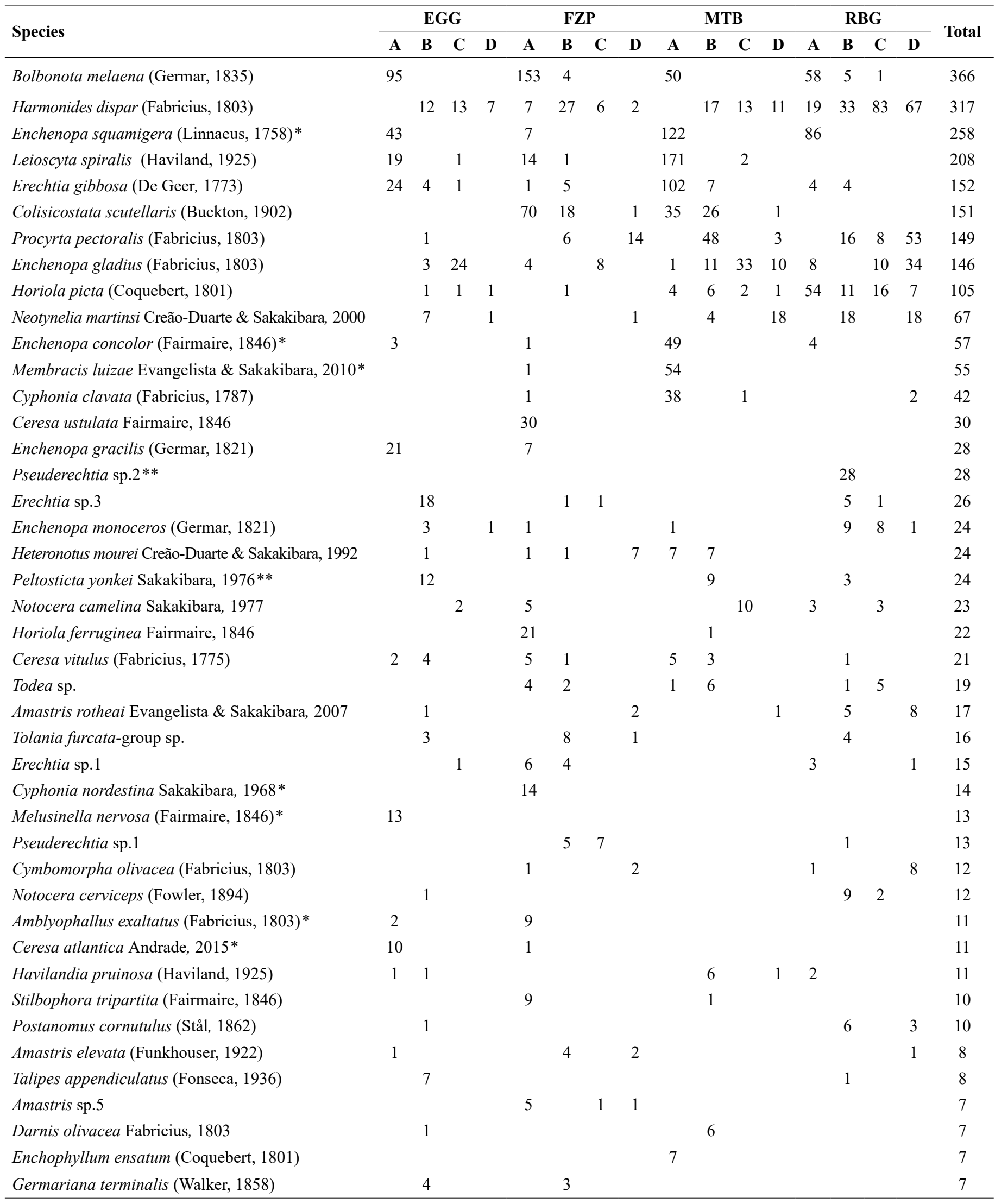


Continuation...

Heteronotus albospinosus Haviland, 1925

Lycoderides capixaba Sakakibara, 2013

Enchophyllum nigrocupreum (Walker, 1858)

Erechtia $\mathrm{sp} .2$

Pseuderechtia neivai (Fonseca, 1941)

Tolania peltacauda-group sp.1

Anobilia splendida Tode, 1966

Enchenopa sp.

Tropidoscyta torva (Germar, 1835)

Amastris sp.

Euwalkeria sp.

Sundarion sp.

Amastris guttata Fonseca, 1942

Amastris sp.1

Calloconophora sp.

Eumela fornicata (Germar, 1821)

Micrutalis sp.1

Amastris funkhouseri Haviland, 1925

Amastris sp.6

Amastris sp.7

Bocydium sp.

Ceresa sp.

Cymbomorpha sp.2

Cymbomorpha vaginata (Germar, 1835)

Enchenopa auridorsa Sakakibara \& Marques, 2007

Membracis sp. 1

Micrutalis binaria (Fairmaire, 1846)

Neotynelia pubescens (Fabricius, 1803)

Notogonioides sinopae Sakakibara, 1996

Potnia diringshofeni Creão-Duarte \& Sakakibara, 1997

Smiliorachis sp.1

Stictopelta sp.

Tolania peltacauda-group sp.2

Amastris sp. 2

Amastris sp.4

Anobilia nigra Tode, 1966

Cladonota apicalis (Stål, 1869)

Cymbomorpha sp.1

Harmonides sp.

Membracis sp. 2

Membracis tectigera Olivier, 1792

Micrutalis sp.2

Micrutalis sp.3

Micrutalis tripunctata (Fairmaire, 1846)

Neotynelia nigra (Funkhouser, 1940)

Neotynelia vertebralis (Fairmaire, 1846)

Paraceresa brasiliensis Remes Lenicov, 1971

Smiliorachis sp.2

13

3

4

24

2

1

2

1

1

1

1

1

2

1

2

2

2

2

1

1

2

2

1

1

1

24

23

23

23

23

3

2

2

2

2

1

7
7

6

6

6

5

5

4

(

3

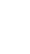

3

5

3

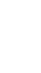

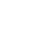


Protocol for Membracidae inventory

Table 2. Sampling efficiency and regression among species abundance and richness of Membracidae for the methods of active collection, sticky cards in the canopy, sticky cards in the lower stratum and a light trap used in four areas of the Atlantic Forest of Paraíba from May 2015 to April 2016. N, sampling units.

\begin{tabular}{lcccc}
\hline Method & Abundance & Richness & N & Efficiency \\
\hline Active & 1517 & 42 & 120 & $0.35 \pm 0.38$ \\
Canopy & 542 & 53 & 120 & $0.44 \pm 0.42$ \\
Lower & 274 & 22 & 120 & $0.18 \pm 0.16$ \\
Light & 345 & 42 & 40 & $1.05 \pm 0.66$ \\
\hline
\end{tabular}

permanence in the field to five days should not adversely impact the final result of the inventory and will reduce the total cost of the protocol.

\section{Discussion}

The combination of the different methods used in the present study for the collection of Membracidae is ideal for the efficient sampling of a given area, which was confirmed by our results and corroborates the proposed hypothesis. However, depending on the goals to be achieved and/or available logistics, some methods may be considered more appropriate and combined in different ways. The active collection, sticky cards in the canopy and light traps are the most indicated methods for collecting a larger number of Membracidae species in the Atlantic Forest. If it is impossible to use a light trap, it is necessary to combine active collection and sticky cards in the canopy and lower stratum, and if it is impossible to combine methods, active collection is the most preferred because of its low cost. However, it should be noted that the efficacy of this method is directly linked to the experience and ability of collectors.

The abundance of specimens collected by the methods used indicates that active collection is the most promising, and this method is very different from the other methods used. Sticky cards
Table 3. Jaccard similarity index and complementarity (in bold) of four collection methods (active collection, sticky cards in the canopy, sticky cards in the lower stratum, and a light trap) of Membracidae applied in four areas of the Atlantic Forest of Paraíba from May 2015 to April 2016.

\begin{tabular}{lcccc}
\hline & Active & Canopy & Lower & Light \\
\hline Active & & $\mathbf{0 . 6 9 8 6}$ & $\mathbf{0 . 7 4 5 1}$ & $\mathbf{0 . 7 6 1 2}$ \\
Canopy & 0.3014 & & $\mathbf{0 . 7 5 0 0}$ & $\mathbf{0 . 7 2 9 7}$ \\
Lower & 0.2549 & 0.2500 & & $\mathbf{0 . 8 1 1 3}$ \\
Light & 0.2388 & 0.2703 & 0.1887 & \\
\hline
\end{tabular}

and light traps are attractive methods and, as such, have little effect on gregarious species, such as Bolbonota melaena and Enchenopa squamigera, and subsocial species as Leioscyta spiralis and Erechtia gibbosa (De Geer, 1773) (for notes on the nomenclature used for behaviors see Lin 2006, tab. 1). Species that exhibit this behavior are reluctant to abandon eggs and nymphs (Tallamy \& Wood 1986, Godoy et al. 2006), which greatly facilitates the capture of these insects in active collection. This is the reason why so many individuals from the same species are collected by this method and the reason why these four species contribute to more than one-third of the total abundance.

When the richness is compared according to method used, sticky cards in the canopy is the best method, and this result is also maintained when the collection option is limited to a certain number of individuals per method, as shown by rarefaction. The Membracidae inhabit the parts of plants that are more exposed to light, such as apical branches and inflorescences (Creão-Duarte et al. 2017), and therefore were recognized as sun loving insects (Funkhouser 1950). As the forest canopy is the habitat where this condition is higher, these insects naturally occur in this location in greater diversity, and sticky cards are one of the best methods to access this fauna (Kopp \& Yonke 1970, Johnson \& Freytag 1997, Wallace \& Troyano 2006).

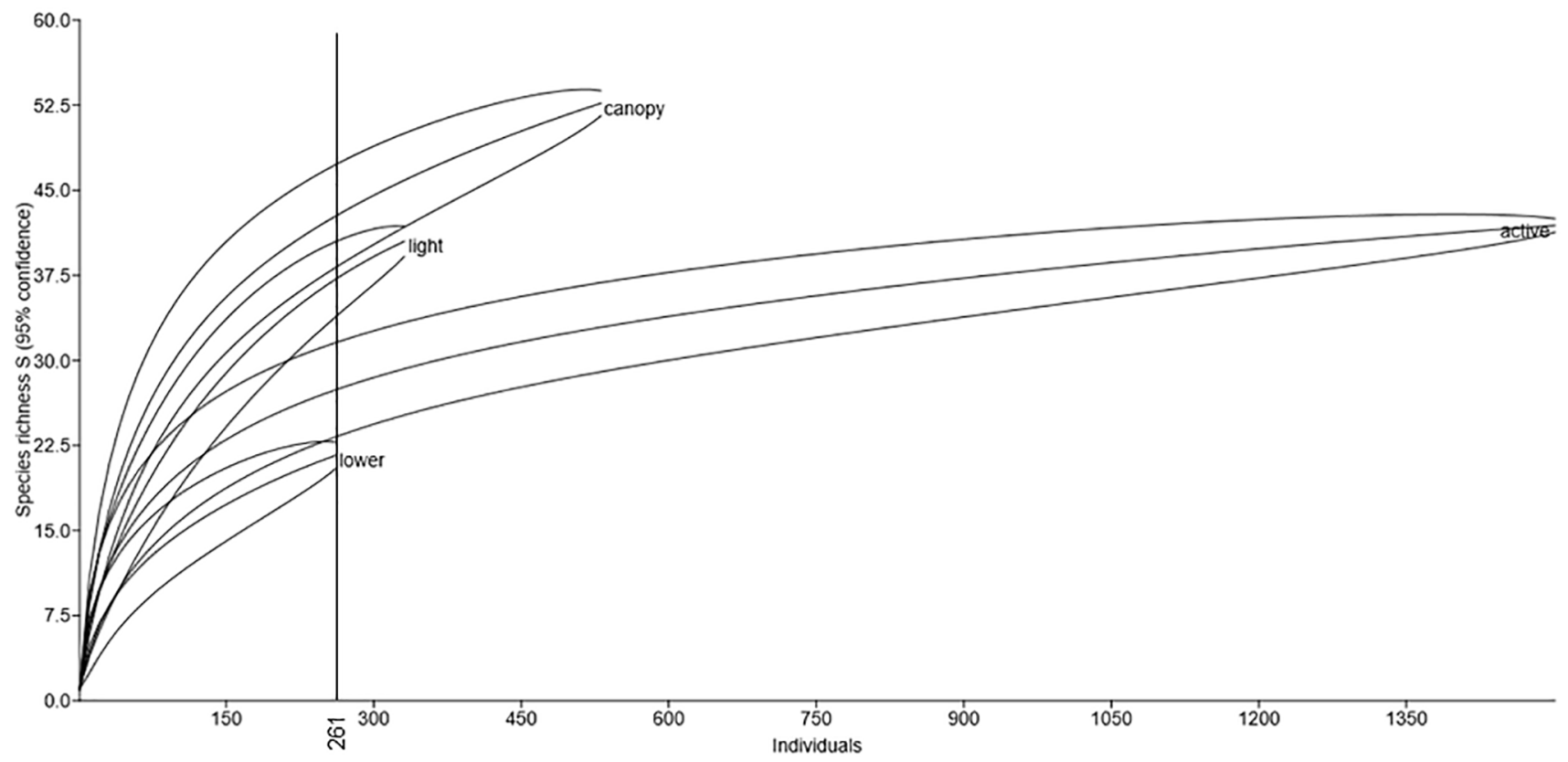

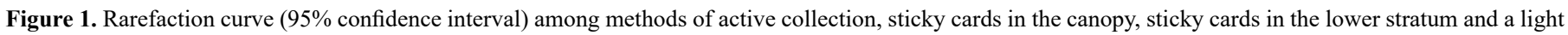
trap for Membracidae in four areas of the Atlantic Forest of Paraíba, collected from May 2015 to April 2016. 


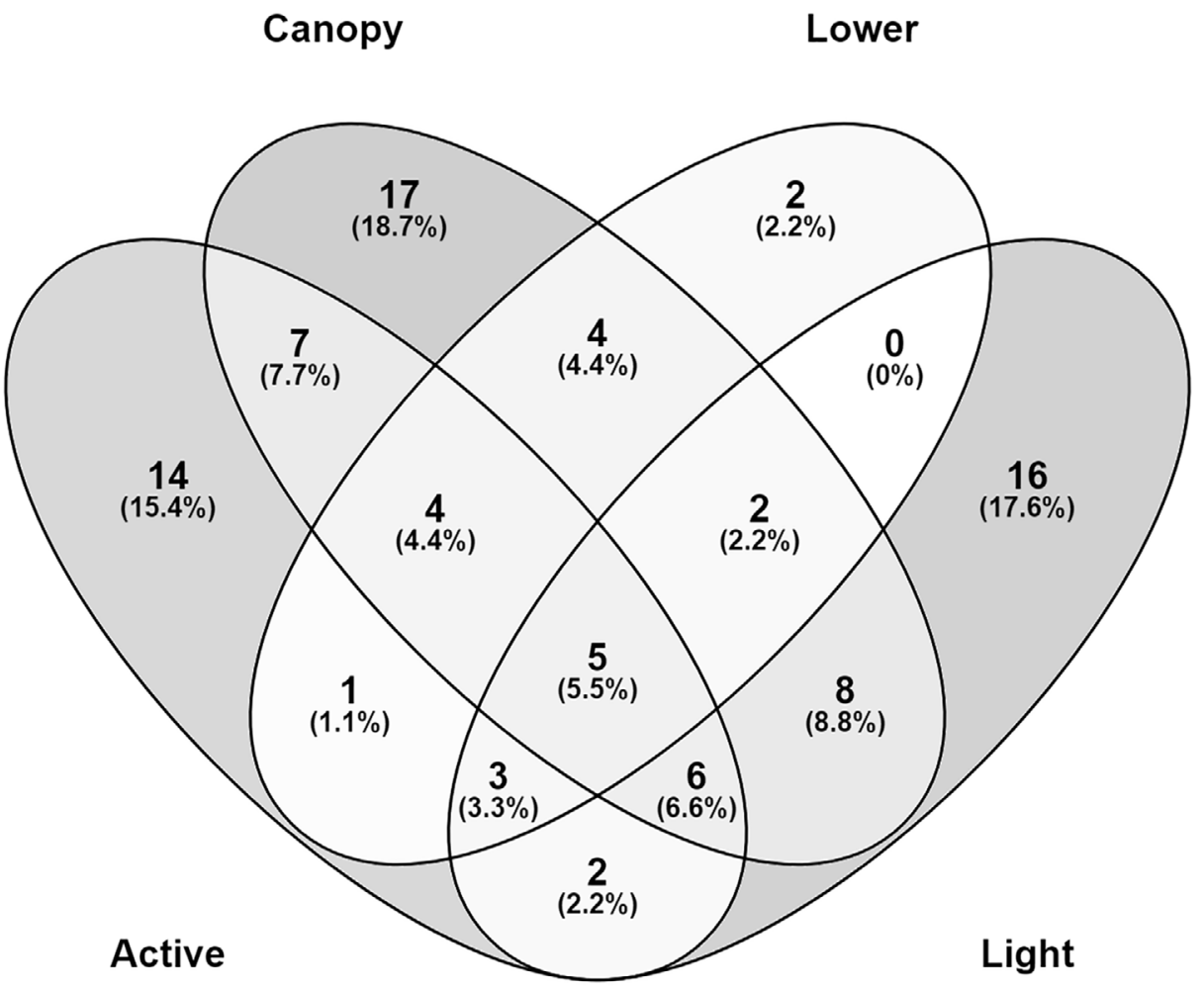

Figure 2. Venn diagram produced from shared and unique species of Membracidae collected in four areas of the Atlantic Forest of Paraíba from May 2015 to April 2016, using methods of active collection, sticky cards in the canopy, sticky cards in the lower stratum and a light trap.

Table 4. Sampling sufficiency of Membracidae collected in four areas of the Atlantic Forest of Paraíba from May 2015 to April 2016, using methods of active collection, sticky cards in the canopy, sticky cards in the lower stratum and a light trap. EGG, RPPN Engenho Gargaú; FZP, RPPN Fazenda Pacatuba; MTB, RVS Mata do Buraquinho; RBG, REBIO Guaribas. N, abundance; S, species richness.

\begin{tabular}{lcccc}
\hline & RBG & MTB & FZP & EGG \\
\hline N & 789 & 929 & 563 & 397 \\
S & 48 & 36 & 58 & 41 \\
Singletons & 11 & 11 & 21 & 12 \\
Doubletons & 9 & 3 & 10 & 7 \\
Uniques & 15 & 13 & 26 & 16 \\
Duplicates & 11 & 4 & 9 & 10 \\
1. Estimators of abundance & & & & \\
ACE & 56.11 & 50.36 & 83.51 & 53.58 \\
Chao 1 & 53.49 & 49.73 & 77.06 & 49.23 \\
Mean richness estimate & 54.80 & 50.05 & 80.29 & 51.41 \\
Sampling sufficiency (\%) & 87.59 & 71.93 & 72.24 & 79.76 \\
2. Estimators of incidence & & & & \\
ICE & 62.51 & 49.95 & 90.8 & 61.33 \\
Chao 2 & 56.66 & 51.44 & 90.18 & 51.8 \\
Jackknife 1 & 62.85 & 48.87 & 83.74 & 56.84 \\
Jackknife 2 & 66.88 & 57.72 & 100.49 & 62.82 \\
Bootstrap & 55.22 & 41.29 & 68.97 & 48.33 \\
Mean richness estimate & 60.82 & 49.85 & 86.84 & 56.22 \\
Sampling sufficiency (\%) & 78.92 & 72.22 & 66.79 & 72.92 \\
\hline
\end{tabular}

The collection methods exhibited high complementarity, which explains the need for combining different methods. The species recorded in the light trap and sticky cards of the lower stratum exhibited greater complementarity and, consequently, lower fauna similarity. These data suggest the stratification of the treehopper fauna's composition in the studied areas, where species such as Enchenopa gladius and Notocera camelina Sakakibara, 1977 are most collected on the sticky cards placed in the lower strata, compared to the upper strata (Lourenço 2017). The vertical variation in arthropod fauna from different forest strata of tropical forests (Campos et al. 2006, Grimbacher \& Stork 2007) it was also registered for Membracidae by Mason \& Loye (1981) and Johnson \& Freytag (1997).

Lower complementarity and, consequently, greater fauna similarity occurred among sticky cards placed in the canopy and active collection at the border (Table 3), which are places where habitat conditions (tender parts of plants exposed to the sun) are similar; therefore, a more similar Membracidae fauna is expected (Creão-Duarte et al. 2017). The results of Davis \& Sutton (1998), who indicated that invertebrate communities typical of the forest canopy (dorsal border) can move, in whole or in part, from the canopy to areas near the border, contribute to explaining this similarity. Even considering that the border effects resulting from forest fragmentation have marked effects on the floristic and faunal composition of the fragments, especially when the latter are small, some groups of insects may increase at the border (Laurance et al. 2002), including Membracidae, which rely on a large community of attendant ants (Dejean \& Giberneau 2000).

As expected, the species composition resulting from active collection differed from that resulting from all other methods due to the very nature of the method, which is subject to the experience and 
Table 5. Sampling sufficiency of Membracidae collected in four areas of the Atlantic Forest of Paraíba from May 2015 to April 2016, using methods of active collection, sticky cards in the canopy, sticky cards in the lower stratum and a light trap. Abundance estimators: ACE and Chao 1; Incidence estimators: ICE, Chao 2, Jackknife 1, Jackknife 2 and Bootstrap. EGG, RPPN Engenho Gargaú; FZP, RPPN Fazenda Pacatuba; MTB, RVS Mata do Buraquinho; RBG, REBIO Guaribas. $\mathrm{N}$, abundance; $\mathrm{S}$, species richness.

\begin{tabular}{|c|c|c|c|c|c|c|}
\hline & $\mathbf{N}$ & $\mathbf{S}$ & $\begin{array}{l}\text { Mean abundance } \\
\text { estimate }\end{array}$ & $\begin{array}{l}\text { Sampling sufficiency } \\
\text { (abundance) } \%\end{array}$ & $\begin{array}{l}\text { Mean incidence } \\
\text { estimate }\end{array}$ & $\begin{array}{l}\text { Sampling sufficiency } \\
\text { (incidence) } \%\end{array}$ \\
\hline RBG Active & 245 & 13 & 13.76 & 94.48 & 19.09 & 68.08 \\
\hline RBG Canopy & 173 & 27 & 39.93 & 67.63 & 39.45 & 68.45 \\
\hline RBG Lower & 137 & 10 & 10.88 & 91.95 & 12.33 & 81.10 \\
\hline RBG Light & 234 & 26 & 29.22 & 88.98 & 33.23 & 78.25 \\
\hline MTB Lower & 63 & 8 & 21.26 & 42.34 & 15.01 & 59.96 \\
\hline MTB Light & 51 & 13 & 46.20 & 25.98 & 26.78 & 44.81 \\
\hline FZP Active & 386 & 31 & 48.42 & 64.03 & 46.10 & 67.25 \\
\hline FZP Canopy & 100 & 22 & 32.23 & 68.27 & 31.34 & 70.20 \\
\hline EGG Canopy & 102 & 27 & 35.86 & 75.29 & 42.66 & 63.30 \\
\hline EGG Lower & 47 & 8 & 13.32 & 60.06 & 12.64 & 63.29 \\
\hline EGG Light & 10 & 4 & 9.78 & 40.90 & 8.05 & 49.70 \\
\hline
\end{tabular}

ability of the collectors, whereas the other methods are methods that attract a species. The composition of divergent species such as those inventoried by sticky cards in the canopy and in the lower stratum are due to the differences in fauna that naturally exist in the vertical strata of the rainforest (Charles \& Basset 2005, Brehm 2007). Compositions of similar species - such as those inventoried using sticky cards in the canopy and by use of the light trap — result from these methods accessing species that inhabit the same sites, predominantly the canopy.

The lack of a list of species of Membracidae for the areas where the protocol was applied seems to prevent any comparison to estimate the reliability of the diversity sampled. Similar previous situations have determined the need to know stop rules, i.e., indicators that the sampling performed is sufficient (Magurran 2011). The representation of at least two specimens per species collected was the stop rule suggested by Colwell \& Coddington (1994); when species accumulation curves reach the asymptote is also recognized as an indication of sample sufficiency, although large-scale collecting efforts do not ensure this (Longino et al. 2002). Coddington et al. (1991) suggest that a sampling intensity of 10:1 (specimens:species) for tropical rainforest conditions would be sufficient for a reliable richness estimate. Sørensen et al. (2002) suggested 30-50:1 for the assemblages of spiders in a montane forest. Cardoso (2009) considers that an inventory can be considered "reasonable" when approximately $50 \%$ of the estimated species are sampled, "comprehensive" when $70-80 \%$ of the estimated species are sampled and "exhaustive" when it reaches $90 \%$ of species.

When we consider our results, by area, regarding these stop rules, we conclude that they are satisfactory and meet the expectations of a protocol. Sampling sufficiency by area may be classified as comprehensive according to Cardoso (2009); we observed that our results exhibit values of specimens/species better than those suggested by Sørensen et al. (2002); and even when we consider the proposal by Coddington et al. (1991), which is more rigorous, we observed that the application of the protocol in two of the four areas are within the rigors of the proposals of these authors.

Considering the sampling sufficiency by method, the lowest values were observed in the light traps in three of the four areas and resulted from a high number of singletons and uniques in relation to the number of doubletons and duplicates, which refutes the need for a greater number of samplings using this method; however, expense and logistic difficulties should be weighed against initiatives different from those proposed here.

The combination of collection methods to inventory Membracidae in the Atlantic Forest presented here is the most appropriate. However, for an expeditious survey that includes the largest number of species, ideally, one would use a combination of active collection with a light trap.

\section{Acknowledgments}

The authors are grateful for the support and collection permission granted by area administrators: Refúgio da Vida Silvestre (RVS) Mata do Buraquinho; Reserva Particular do Patrimônio Natural (RPPN) Engenho Gargaú; Reserva Biológica (REBIO) Guaribas; Reserva Particular do Patrimônio Natural (RPPN) Fazenda Pacatuba. VAC and AL thanks Coordenação de Aperfeiçoamento de Pessoal de Nível Superior (CAPES) for research scholarship. APC is grateful to the Conselho Nacional de Desenvolvimento Científico e Tecnológico (CNPq) for research scholarship (proc. \#350052/2014-0) and Fundação de Apoio à Pesquisa do Estado da Paraíba (FAPESQ) for research support. 


\section{Author contributions}

Valberta Alves Cabral: conceptualization and design of the study; field work; material identification and data curation; contribution to manuscript preparation.

Antonio José Creão-Duarte: conceptualization and design of the study; material identification and data curation; original manuscript preparation.

Aline Lourenço: material identification and data curation; field work; contribution to manuscript preparation.

Carolina Nunes Liberal: contribution to manuscript preparation; contribution to critical revision.

Alessandre Pereira-Colavite: field work; contribution to manuscript preparation, review and editing.

\section{Conflicts of interest}

The authors declare no conflict of interest.

\section{References}

AGOSTI, D. \& ALONSO, L.E. 2000. The ALL protocol: a standard protocol for the collection of ground-dwelling ants. In Ants: Standard Methods for Measuring and Monitoring Biodiversity (Agosti, D., Majer, J.D., Alonso, L.E. \& Schultz, T.R., eds.). Smithsonian Institution Press, Washington, p.204-206.

ALONSO, L.E. \& AGOSTI, D. 2000. Biodiversity studies, monitoring, and ants: an overview. In Ants: Standard Methods for Measuring and Monitoring Biodiversity (Agosti, D., Majer, J.D., Alonso, L.E. \& Schultz, T.R., eds.). Smithsonian Institution Press, Washington, p.1-8.

Alvares, C.A., STAPE, J.L., SENTElhas, P.C., DE MORAES GONÇALVES, J.L. \& SPAROVEK, G. 2013. Köppen's Climate classification map for Brazil. Meteorol. Z. 22(6):711-728. https://dx.doi. org/10.1127/0941-2948/2013/0507

BORISKO, J.P., KILGOUR, B.W., STANFIELD, L.W. \& CHRIS JONES, F. 2007. An evaluation of rapid bioassessment protocols for stream benthic invertebrates in Southern Ontario, Canada. Water Qual. Res. J. Can. 42(3):184-193. https://doi.org/10.2166/wqrj.2007.022

BRAGA, R.F., KORASAKI, V., ANDRESEN, E \& LOUZADA, J. 2013. Dung beetle community and functions along a habitat disturbance gradient in the Amazon: a rapid assessment of ecological functions associated to biodiversity. PLoS ONE 8(2):e57786. https://doi.org/10.1371/journal.pone.0057786

BREHM, G. 2007. Contrasting patterns of vertical stratification in two moth families in a Costa Rican lowland rain forest. Basic Appl. Ecol. 8:44-54. https://doi.org/10.1016/j.baae.2006.02.002

BROWN JR., K.S. 1997. Diversity, disturbance, and sustainable use of Neotropical forests: insects as indicators for conservation monitoring. J. Insect Conserv. 1:25-42. https://doi.org/10.1023/A:1018422807610

BUSS, D.F. \& BORGES, E.L. 2008. Application of rapid bioassessment protocols (RBP) for benthic macroinvertebrates in Brazil: comparison between sampling techniques and mesh sizes. Neotrop. Entomol. 37:288295. http://dx.doi.org/10.1590/S1519-566X2008000300007

CAMPOS, R.I., VASCONCELOS, H.L., RIBEIRO, S.P., NEVES, F.S. \& SOARES, J.P. 2006. Relationship between tree size and insect assemblages associated with Anadenanthera macrocarpa. Ecography 29:442-450. https:// doi.org/10.1111/j.2006.0906-7590.04520.x

CARDOSO, P. 2009. Standardization and optimization of arthropod inventories - the case of Iberian spiders. Biodivers. Conserv. 18:3949-3962. https://doi.org/10.1007/s10531-009-9690-7

CARDOSO, P., SCHARFF, N., GASPAR, C., HENRIQUES, S.S., CARVALHO, R., CASTRO, P.H., SCHMIDT, J.B., SILVA, I., SZÜTS, T., CASTRO, A. DE \& CRESPO, L.C. 2008. Rapid biodiversity assessment of spiders (Araneae) using semi-quantitative sampling: a case study in a Mediterranean forest. Insect Conserv. Diver. 1:71-84. https://doi. $\operatorname{org} / 10.1111 / j .1752-4598.2007 .00008 . x$
CHARLES, E. \& BASSET, Y. 2005. Vertical stratification of leaf-beetle assemblages (Coleoptera: Chrysomelidae) in two forest types in Panama. J. Trop. Ecol. 21:329-336. https://doi.org/10.1017/S0266467405002300

CODdington, J.A., GRISWOLD, C.E, SILVA DÁVILA, D., PEÑARANDA, E. \& LARCHER, S.F. 1991. Designing and testing sampling protocols to estimate biodiversity in tropical ecosystems. In The unity of evolutionary biology: Proceedings of the Fourth International Congress of Systematic and Evolutionary Biology (Dudley, E.C., ed.). Dioscorides Press, Portland, p.44-60.

COLWELL, R.K \& CODDINGTON, J.A. 1994. Estimating terrestrial biodiversity through extrapolation. Philos. T. Roy. Soc. B 345:101-118. https://doi.org/10.1098/rstb.1994.0091

COLWELL, R.K. 2013. EstimateS: statistical. estimation of species richness and shared species from samples, version 9.1. Available online: http://viceroy. colorado.edu/estimates/ (accessed on 11 May 2019).

CREÃO-DUARTE, A.J., PEREIRA-COLAVITE, A., SANTOS, W.E. DOS, BARBOSA, S.A., CABRAL, V.A., LOURENÇO, A., BRAGA, I.S. \& SILVA, W.R. DA. 2017. Membracidae diversity (Hemiptera: Auchenorrhyncha) in an Atlantic Forest area, Paraíba, Brazil, with preliminary comments on collection methods, spatial distribution and estimated species richness. B. Mus. Paraense Emílio Goeldi, Ciên. Nat. 12(1):11-21.

DAVIS A.J. \& SUTTON, S.E. 1998. The effects of rain forest canopy loss on arboreal dung beetles in Borneo: implications for the measurement of biodiversity in derived tropical ecosystems. Divers. Distrib. 4:167-173. https://doi.org/10.1046/j.1472-4642.1998.00017.x

DEITZ, L.L. \& WALLACE, M.S. (team leaders). 2010 (and updates). Treehoppers: Aetalionidae, Melizoderidae, and Membracidae (Hemiptera) Available online: http://treehoppers.insectmuseum.org (accessed on 30 Dec 2019).

DEJEAN, A. \& GIBERNAU, M. 2000. A rainforest ant mosaic: the edge effect (Hymenoptera, Formicidae). Sociobiology 35(3):385-401.

DUELLI, P. 1997. Biodiversity evaluation in agricultural landscapes: an approach at two different scales. Agr. Ecosyst. Environ. 62:81-91. https:// doi.org/10.1016/S0167-8809(96)01143-7

EVANGELISTA, O., SAKAKIBARA, A.M. \& TAKIYA, D.M. 2019. Membracidae in Catálogo Taxonômico da Fauna do Brasil. PNUD. Available online: http://fauna.jbrj.gov.br/fauna/faunadobrasil/1304 (accessed on 30 Dec 2019).

EVANGELISTA, O., SAKAKIBARA, A.M., CRYAN, J.R. \& URBAN, J. 2017. A phylogeny of the treehopper subfamily Heteronotinae reveals convergent pronotal traits (Hemiptera: Auchenorrhyncha: Membracidae). Syst. Ent. 42:410-428. https://doi.org/10.1111/syen.12221

FUNKHOUSER, W.D. 1950. Homoptera, Fam. Membracidae. In Genera Insectorum, $208^{\circ}$ fascicle (Wytsman, P., ed.). Louis Desmet Verteneuil, Bruxelles, p.1-383.

GADELHA, Y.E.A., DÁTTILO, W., EVANGELISTA, O. \& LOPES, B.C. 2016. Structure of mutualistic ant-treehopper interactions in the Brazilian Atlantic. J. Trop. Ecol. 32:250-259. https://doi.org/10.1017/S0266 467416000183

GADELHA, Y.E.A., LANGE, D., DÁTTILO, W \& LOPES, B.C. 2017. Phenological phases of the host plant shape plant-treehopper interaction networks. Ecol. Entomol. 42:827-837. https://doi.org/10.1111/een.12457

GILLIES, C.L., HOSE, G.C. \& TURAK, E. 2009. What do qualitative rapid assessment collections of macroinvertebrates represent? A comparison with extensive quantitative sampling. Environ. Monit. Assess. 149:99-112. https:// doi.org/10.1007/s10661-008-0186-9

GODOY, C., MIRANDA, X. \& NISHIDA. K. 2006. Membrácidos de la América Tropical. Editorial INBIO: Santo Domingo de Heredia, p.1-352.

GOTELLI, N.J. \& COWELL, R.K. 2001. Quantifying biodiversity: procedures and pitfalls in the measurement and comparison of species richness. Ecol. Lett. 4:379-391. https://doi.org/10.1046/j.1461-0248.2001.00230.x

GRIMBACHER, P.S \& STORK, N.E. 2007. Vertical stratification of feeding guilds and body size in beetle assemblages from an Australian tropical rainforest. Austral Ecol. 32:77-85. https://doi.org/10.1111/j.14429993.2007.01735.x 
HAMMER, Ø., HARPER, D.A.T. \& RYAN, P.D. 2001. PAST: Paleontological statistics software package for education and data analysis. Palaeontol. Electron. 4(1):1-9.

JOHNSON, M.P. \& FREYTAG, P.H. 1997. Treehoppers (Homoptera: Membracidae) on Pin Oak in Kentucky. J. Kansas Entomol Soc. 70(1):21-30.

JONES, D.T. \& EGGLETON. P. 2000. Sampling termite assemblages in tropical forests: testing a rapid biodiversity assessment protocol. J. Appl. Ecol. 37:191-203. https://doi.org/10.1046/j.13652664.2000. 00464.x

KOPP, D.D. \& YONKE, T.R. 1970. Annotated list of Treehopper species (Homoptera: Membracidae) of Missouri and evaluation of collection methods. T. Missouri Acad. Sci. 4:76-83.

LAURANCE, W.F., LOVEJOY, T.E., VANCONCELOS, H.L., BRUNA, E.M., DIDHAN R.K., STOUFFER, P.C., GASCON, C., BIERREGAARD, R.O., LAURANCE, S.G. \& SAMPAIO, E. 2002. Ecosystem decay of Amazonian Forest fragments: a 22 -year investigation. Conserv. Biol. 16(3):605-618. https://doi.org/10.1046/j.1523-1739.2002.01025.x

LIN, C.P. 2006. Social behavior and life history of membracine treehoppers. J. Nat. Hist. 40:1887-1907. https://doi.org/10.1080/00222930601046618

LIN, C.P., DANFORTH, B.N. \& WOOD, T.K. 2004. Molecular phylogenetics and evolution of maternal care in Membracine treehoppers. Syst. Biol. 53(3):400-421. https://doi.org/10.1080/10635150490445869

LONGINO, J.T., CODDINGTON, J.A. \& COWELL, R.K. 2002. The ant fauna of a tropical rain forest: estimating species richness three different ways. Ecology 83:689-702. https://doi.org/10.1890/0012-9658(2002)083[0689:TA FOAT]2.0.CO;2

LOURENÇO, A. 2017. Estratificação Vertical e Checklist de Membracidae (Hemiptera: Auchenorrhyncha) em Floresta Úmida na Paraíba. Dissertação de mestrado, Universidade Federal da Paraíba, João Pessoa.

MAGURRAN, A.E. 2011. Medindo a Diversidade Biológica. Editora UFPR, Curitiba, p.1-261.

MASON. C.E. \& LOYE, J.E. 1981. Treehoppers (Homoptera: Membracidae) collected at multiple levels in deciduous woodlot in Delaware. Entomol. News 92(2):64-68.
MUELELWA, M.I., FOORD, S.H., DIPPENAAR-SCHOEMAN, A.S. \& STAM, E.M. 2010. Towards a standardized and optimized protocol for rapid assessments: spider species richness and assemblage composition in two savanna vegetation types. Afr. Zool. 45:273-290. https://doi. org/10.3377/004.045.0206

OLIVER, I. \& BEATTIE, A.J. 1996. Designing a cost-effective invertebrate survey: a test of methods for rapid assessment of biodiversity. Ecol. Appl. 62(2):594-607.

OLIVEROS, J.C. 2015. Venny: an interactive tool for comparing lists with Venn's diagrams, version 2.1. Available online: http://bioinfogp.cnb.csic. es/tools/venny/index.html (accessed on 21 July 2019).

SØRENSEN, L.L., CODDINGTON, J.A. \& SCHARFF, N. 2002. Inventorying and estimating subcanopy spider diversity using semi-quantitative sampling methods in an Afromontane forest. Environ. Entomo. 31:319-330. https:// doi.org/10.1603/0046-225X-31.2.319

SOUZA, J.L.P., BACCARO, F.B., LANDEIRO, V.L., FRANKLIN, E. \& MAGNUSSON, W.E. 2012. Trade-offs between complementarity and redundancy in the use of different sampling techniques for ground-dwelling ant assemblages. Appl. Soil Ecol. 56:63-73. https://doi.org/10.1016/j. apsoil.2012.01.004

TALLAMY D.W. \& WOOD, T.K. 1986. Convergence patterns in subsocial insects. Annu. Rev. Entomol. 31:369-390. https://doi.org/10.1146/annurev. en.31.010186.002101

WALLACE, M.S. \& TROYANO, N.M. 2006. The oak-feeding Smilinae treehoppers (Hemiptera, Membracidae) of Delaware Water Gap Recreation Area. J. Penn. Acad. Sci. 80(1):28-34.

WOOD, T.K. 1993. Diversity in the New World Membracidae. Annu. Rev. Entomol 38:409-433. https://doi.org/10.1146/annurev.en.38.010193.002205

Received: 02/09/2019

Revised: 07/04/2020

Accepted: 08/04/2020

Published online: 05/06/2020 